\title{
Aggregate Fiscal Stabilisation Policy: Panacea or Scapegoat?*
}

Gábor P. Kiss

In many cases, analyses of fiscal stabilisation are characterised by errors and omissions. This study addresses these issues. In addition to the operation of automatic stabilisers and the stabilising effect of the EU budget, we examine whether or not a stabilisation policy based on a significant change in the budget deficit can be sustainable and successful. While the economic growth rate is affected by the impulse from the changes in the deficit, the level of economic performance is affected by the deficit. However, the accumulated debt resulting from the persistent deficit is growing faster than the impact on GDP, and thus the debt ratio could start rising sharply in the foreseeable future. We show that a continuous increase in demand may be self-financing only in the unlikely event that the value of the medium-term fiscal multiplier closely approximated 3, i.e. the impact in real terms of a nominal impulse would permanently triple. A lasting, sizeable general demand increase is therefore not a panacea; however, the literature suggests that its alternatives, i.e. structural reform and targeted measures, are more appropriate and less costly for achieving higher trends of GDP growth. Similar results were obtained also in simulations based on the Hungarian experience of targeted measures.

Journal of Economic Literature (JEL) codes: E32, E61, E62, H62, H63

Keywords: fiscal policy, general demand increase, fiscal multiplier, economic policy coordination

\section{Introduction}

The economic crisis that started in 2007 highlighted the stabilisation role of monetary policy. By contrast, fiscal policy was less active in many countries, including the European Union, despite its traditionally strong role in economic stabilisation. The question arises as to what extent this may have contributed to the fact that economic growth did not return to its pre-crisis trend (Lehmann et al 2020).

* The papers in this issue contain the views of the authors which are not necessarily the same as the official views of the Magyar Nemzeti Bank.

Gábor P. Kiss is a Head of Department at the Magyar Nemzeti Bank.E-mail: kissg@mnb.hu

The author wishes to express his thanks particularly to Zoltán Bögöthy and Katalin Szőke for their help, as well as to Gergely Baksay, Endre Morvay and the two anonymous reviewers for their comments. Any remaining errors are the responsibility of the author.

The Hungarian manuscript was received on 17 March 2020.

DOI: http://doi.org/10.33893/FER.19.2.5587 
The definition of fiscal policy includes the full range of policies concerning the budget balance as well as taxes and expenditures (Cottarelli-Keen 2012, Tanzi - Zee 1997, IMF 2015). In the context of the current fiscal policy, the question arises as to whether this policy is sustainable, as "the continued need for government financing leads to an ever-increasing public debt" (Domar 1944). Traditional functions of fiscal policy include stabilising the cyclically fluctuating economic activity, providing (allocating) public goods and redistributing income (Musgrave 1959). Discharging these functions has a direct (allocation and stabilisation) or indirect (redistribution) effect on economic performance. In some circumstances, it can be assumed that this effect may extend, in addition to the level of GDP, to potential growth rates. However, there are a number of misunderstandings about fiscal stabilisation. In the following sections, we address some current issues.

We begin section 2 by showing that growth is affected not by the deficit, but rather by the change in the deficit. Subsequently, we explain the theory regarding the effect and multiplier of this change. Section 3 responds to opinions that ignore the consensus on the optimal characteristics of discretionary measures. ${ }^{1}$ The extreme form of this is the rejection of temporary nature, which can lead to a prolonged fiscal expansion. We prove by simple simulation that this is not possible and the obstacles are not the specific values of the Maastricht criteria.

Section 4 seeks to recall automatic stabilisers that are often ignored in the literature. Neither their effect nor the principle of "letting automatic stabilisers operate" should be forgotten. Section 5 shows that the estimation uncertainty and ex-post revision of the output gap often impede the smooth operation of automatic stabilisers and, in fact - through incorrect estimation of the cycle - this actually results in a procyclical fiscal policy. We also show an example where the aspects of stabilisation and sustainability are conflicting.

Section 6 questions the reality of the idea according to which an EU budget of a size that could lead to effective stabilisation at the level of monetary union could be created. Section 7 challenges the view that, in addition to monetary policy, it is only worth considering the instrument of the fiscal impulse to aggregate demand. On the one hand, it is recalled that the targeting of fiscal policy is crucial, as the impact of the individual measures on short-term and long-term output is very different. We show that budget-neutral measures, which apparently do not have an effect on aggregate demand, can still have positive effect. ${ }^{2}$ On the other hand, we draw attention to the fact that other economic policy instruments have come to the fore. Structural and competitiveness reforms, as well as macro- and micro-

\footnotetext{
${ }^{1}$ Discretionary measures should be timely, temporary and targeted. Recently, the importance of the timely character, i.e., avoiding delays is recognised in the literature at most, which is necessary to avoid procyclicality.

2 Matolcsy (2015), Palotai (2017), Baksay and Csomós (2014), Szoboszlai et al. (2018)
} 
prudential instruments, in addition to the function of stabilisation, can also support potential growth.

\section{Fiscal impulse and fiscal multipliers}

Fiscal policy in aggregate terms (disregarding the revenue-expenditure structure) has a significant impact on economic growth when the deficit changes significantly and the value of the multiplier is high. There are different estimates of the value of short-term multipliers, whereas even the sign of long-term multipliers is uncertain. In the following, we first demonstrate the fact that it is not the deficit itself, but rather the change therein - i.e. the fiscal impulse - that affects growth. We then present estimates and theories regarding multipliers and illustrate how much of a difference it can make if we choose one or the other.

The short-term impact of fiscal policy is presented below following the deduction of Chand (1993).

In a closed economy, the following identities can be formulated:

$$
\begin{gathered}
Y=C+I+G \\
T=t(Y),
\end{gathered}
$$

where $Y$ is economic output, $C$ is household consumption, $I$ is private investment, $G$ is government expenditure, $T$ is government tax revenue, and $t$ is the effective tax rate.

Now let us assume that $I$ and $G$ are determined exogenously. In the case of consumption, we assume that it is the proportional share of the income in the given year:

$$
C=c(Y-T),
$$

where $c$ is the marginal propensity to consume.

Based on (1), (2) and (3) relations, by introducing the $\alpha$ multiplier:

$$
Y=\frac{1}{1-c(1-t)}(I+G)=\alpha(I+G),
$$


and following the deduction of Chand (1993), by the total differentiation and quantification of this in the previous period, we obtain the following result:

$$
\Delta Y=\alpha_{-1}(\Delta I+\Delta G)+\left(I_{-1}+G_{-1}\right)\left\{-\alpha_{-1}^{2} c_{-1} \Delta t+\left(1-t_{-1}\right) \alpha_{-1}^{2} \Delta c\right\},
$$

that is, the change in GDP depends on the change in the two variables assumed to be exogenous ( $I$ and $G$ ) multiplied by the multiplier of the base year, and on the change in the multiplier in the current year, which depends on the tax rate and on the marginal propensity to consume.

The effect of changes in the effective tax rate on tax revenue:

$$
\Delta t Y_{-1}=\Delta T-t_{-1} \Delta Y
$$

The effect of changes in marginal propensity to consume on consumption:

$$
\Delta c Y_{-1}=\frac{\Delta C}{1-t_{-1}}-c_{-1} \Delta Y .
$$

Using $Y=\alpha(I+G)$, the equation describing the change in GDP (5) can be rewritten:

$$
\Delta Y=\alpha_{-1}(\Delta I+\Delta G)+Y_{-1}\left\{-\alpha_{-1} c_{-1} \Delta t+\left(1-t_{-1}\right) \alpha_{-1} \Delta c\right\} .
$$

Substituting the equations describing the effect of the change in the effective tax rate (6) and the marginal propensity to consume (7) and dividing by $Y_{-1}$

$$
\frac{\Delta Y}{Y_{-1}}=\alpha_{-1}\left\{\left(\frac{\Delta I}{I_{-1}} \frac{I_{-1}}{Y_{-1}}+\frac{\Delta G}{G_{-1}} \frac{G_{-1}}{Y_{-1}}\right)-c t_{-1}\left(\frac{\Delta T}{T_{-1}}-\frac{\Delta Y}{Y_{-1}}\right)+c_{-1}\left(\frac{\Delta C}{C_{-1}}-\frac{\Delta Y}{Y_{-1}}\right)\right\} .
$$

If we subtract the neutral trend of balanced growth $(n)$ from the above equation breaking down the actual growth, the following equation is obtained:

$$
\begin{array}{r}
\frac{\Delta Y}{Y_{-1}}-n=\alpha_{-1}\left\{\left(\frac{\Delta I}{I_{-1}}-n\right) \frac{I_{-1}}{Y_{-1}}+\left[\left(\frac{\Delta G}{G_{-1}}-n\right) \frac{G_{-1}}{Y_{-1}}\right.\right. \\
\left.\left.-c t_{-1}\left(\frac{\Delta T}{T_{-1}}-\frac{\Delta Y}{Y_{-1}}\right)\right]+c_{-1}\left(\frac{\Delta C}{C_{-1}}-\frac{\Delta Y}{Y_{-1}}\right)\right\} .
\end{array}
$$

However, the question is what can be considered a measure in the case of increasing spending. Following Chand's (1993) deduction, it can be concluded that if the marginal propensity to consume $(c)$ and the effective tax rate $(t)$ do not change, then actual economic growth can only deviate from the trend $(n)$ if the increase in investments or in government expenditure differs from the same growth trend value $(n)$ :

$$
\frac{\Delta Y}{Y_{-1}}=\alpha_{-1}\left(\frac{\Delta I}{I_{-1}} \frac{I_{-1}}{Y_{-1}}+\frac{\Delta G}{G_{-1}} \frac{G_{-1}}{Y_{-1}}\right)
$$


The deviation of the growth rate of government expenditure from the value of $n$ represents a measure, the deviation of taxes from economic growth - apart from the progressive tax system - also indicates a measure, namely the change of the effective tax rate. It is clear from the formula that short-term GDP growth is not affected by the fiscal balance, but by its change. As a consequence, maintaining a continuously high level of short-term economic growth would require a continuing deterioration of the fiscal balance. However, a deficit increasing for a long time could at some point result in unfinanceable public debt and uncredible fiscal policy.

In formula (10), the part of the budget items in square brackets, except for the marginal propensity to consume, is the same as the so-called "Dutch" fiscal impulse (Chand 1977):

$$
\frac{F I}{Y_{-1}}=\left(\frac{\Delta G}{G_{-1}}-n\right) \frac{G_{-1}}{Y_{-1}}-\left(\frac{\Delta T}{T_{-1}}-\frac{\Delta Y}{Y_{-1}}\right) \frac{T_{-1}}{Y_{-1}} .
$$

This "Dutch" fiscal impulse indicator measures the impact of discretionary policy by eliminating the budgetary impact of changes in the economic cycle, and thus it can also be seen as the difference between the cyclically-adjusted budget balances in the current and base years. This indicator refers in principle to the first-round effect of discretionary measures, but does not adjust tax revenues for marginal propensity to consume. Now let us resolve the assumption that investment is an exogenous variable and the economy is closed. This way, discretionary measures also have an effect through the investment multiplier, and with the introduction of openness, imports $(M)$ and exports $(X)$ can also appear, which also affects the impact of fiscal policy. As for the consumption multiplier, this means that its size decreases by taking into account the extent of import marginal propensity $\left(m_{C}\right)$ associated with consumption:

$$
\alpha=\frac{1}{1-c(1-t)+m_{C}} .
$$

Regarding the impact of fiscal policy, economic theory provides different answers, and this diversity is also reflected in the results of empirical studies. In the following, we briefly deal with the theoretical and then with the empirical approach.

Most of the modern theories accept that the short-term fiscal impact is determined by New Keynesian mechanisms, due to the fact that competition and price and wage flexibility are not perfect. All these could lead to a Keynesian lack of demand at some points in the economic cycle, meaning that a fiscal expansion will increase household disposable income, private consumption and GDP due to sticky prices and wages. This direct Keynesian effect is strengthened, for example, by the capital market imperfections and the high proportion of liquidity-constrained consumers, but may be weakened or offset by other non-Keynesian effects. 
Such a weakening effect can be achieved if markets still operate more efficiently, as well as by economic openness [formula (13)], the compensating effect of labour market and competitiveness, and interest rate and exchange rate reactions. Interest rates have an effect via the interest rate sensitivity of investments ${ }^{3}$ on the one hand, and via the wealth effect on the other hand, and finally via the effect exerted on net exports by changing the interest premium. ${ }^{4}$ The heterogeneity of households has also a weakening effect, as these different income/wealth groups can compensate the effect of the measure through the gradual development of different lending (Hayashi 1987) or savings (Mankiw 2000) offsetting mechanisms.

An offsetting effect - and even a negative multiplier - may result from the assumption of the neoclassical school (Bernheim 1989) that the strong crowdingout effect of fiscal expansion reduces private consumption and investment, while the positive effect of labour supply on GDP is not significant. According to this argument, capital market equilibrium requires households to buy government bonds at the time of fiscal expansion and to curb private investment in order to smooth savings (Strulik - Trimborn 2013). This can lead to diminishing the capital stock and a decline in production, which will only recover in the long term.

Modern theories differ in the assessment of the size of fiscal multiplier in the medium to long term. According to the synthesis of neoclassical and Keynesian theory, the New Keynesian mechanisms act in the short term, but in the long term, neoclassical correlations prevail. Even capital stock lower in the medium term (negative medium-term multiplier) returns to equilibrium in the long run (zero long-term multiplier).

In the traditional New Keynesian approach, the multiplier decreases to zero in the medium and long term, and the economy returns to equilibrium with the natural rate of unemployment. However, in the wake of the crisis, an increasing number of economists believe that the multiplier can remain positive. They argue that potential output is endogenous, and not independent of the path of aggregate demand. Namely, during a prolonged recession, high cyclical unemployment may transform into structural unemployment, the knowledge of labour force is devalued and the labour force is excluded from the labour market, thus reducing potential GDP (DeLong - Summers 2012). Thus, the fiscal expansion that prevents this, ceteris paribus increases potential output, i.e. it may result in a positive multiplier even in the longer run.

\footnotetext{
${ }^{3}$ Three factors of investment can be distinguished. In the case of autonomous investment, the marginal propensity to invest is zero. This may include public investment. The other two components of investment depend on income and interest, respectively. The inclusion of interest rates shows the channel that investments are sensitive to changes in the capital costs.

${ }^{4}$ This channel may have an effect in a weak Keynesian or non-Keynesian approach. One explanation is that the credibility effect of fiscal expansion/restriction may increase/decrease the interest premium. This could appreciate/depreciate the exchange rate and reduce/increase net exports, certainly depending on whether or not monetary policy responds. Another explanation is that higher/lower interest premium can curb/boost direct investment inflows, which can worsen/improve companies' export competitiveness.
} 
The different short- and medium-term fiscal multipliers of modern theories are summarised in schematic Figure 1, plotting the possible trajectories of the effect of a fiscal expansion as a function of time. This draws the attention to the fact that the short-term multiplier differs greatly from the medium-term multiplier in all theoretical frameworks and this should not be ignored when assessing fiscal stimulus (Guest - Makin 2011). The upper dashed line shows the effect related to the phenomenon of hysteresis, where demand-increasing fiscal policy can have a positive effect even in the long term through higher potential GDP. The next dashed line shows a weak Keynesian effect, where the correlation between the fiscal stimulus and GDP is also positive, but in the longer term it is zero. The middle, thick line gives an example of a response function corresponding to the synthesis of neoclassical and Keynesian theory, where in the medium term the channels of opposite directions exceed the Keynesian effects and in the long term this also tends to zero. The lower dotted line represents the reaction function of the neoclassical fiscal effect. Here, non-Keynesian channels will outweigh even in the short term, making the overall impact negative sooner and then also zero in the long term. This figure not only illustrates that the short- and medium-term fiscal multipliers are different, but also that the short-term multiplier should not be identified with the first-year multiplier either. ${ }^{5}$

\section{Figure 1 \\ Fiscal multipliers at the same degree of impulse}

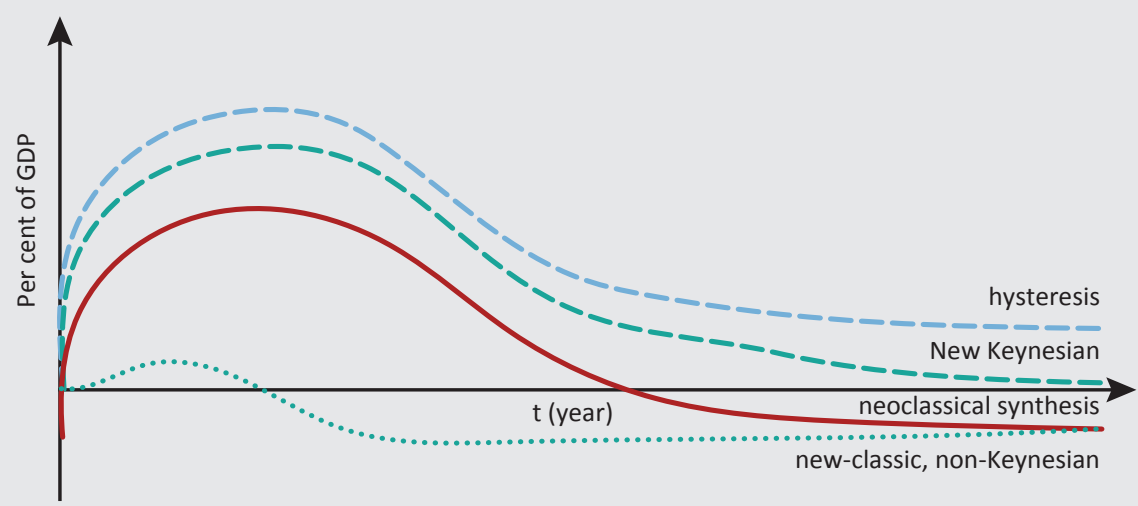

Note: The scaling of the GDP axis is intentionally missing. The purpose of the figure is to present a schema using the relative curves. Specific values depend on various factors (e.g. tax or expenditure, etc.) and are very cycle-dependent in the short-term.

Source: Plotted based on Horváth et al. (2006) and Strulik - Trimborn (2013)

Just as the theory assumes different short-, medium-, and long-term multipliers, the empirical results are also diverse. A common feature of these model-based and econometric estimates is that according to them even the impact of permanent

\footnotetext{
${ }^{5}$ For similar figures, see Strulik - Trimborn (2013), Figure 2; Horváth et al. (2006), Figure 1.
} 
fiscal measures will disappear within five years (Batini et al. 2014). This process is not linear, but shows an inverse $U$-shape with the maximum occurring in the second year (Coenen et al. 2012). If a general increase in demand is proportional for all items, almost one-half of expenditures appears directly at the level of nominal GDP, but only a smaller part of this appears in the volume (e.g. investment, but spread over 20-25 years), and a larger in the deflator (e.g. public wage increase). Moreover, due to the direct tax content of public expenditures, about one-fifth of the impulse is immediately returned as tax revenue, and thus the net impulse is that much smaller. The above factors explain why, by default, the multiplier of a general demand increase identified by a gross impulse is moderate.

On the one hand, in terms of the magnitude and trajectory of the effect, it is of paramount importance whether the fiscal shock is temporary or permanent, and in what composition it realised. The literature on expansive (non-Keynesian) fiscal consolidation has assigned a crucial role to the composition of the adjustment (e.g. Perotti 1996). The importance of the "Composition Matters" issue will be discussed in the last section. The size of the debt stock is also important, as the multiplier is higher when the debt ratio is lower (Huidrom et al. 2016). At higher debt ratios, the increase in yields as a result of deficit-increasing measures may affect the economy as a whole and thus crowd out private investment and consumption (Bi et al. 2014).

On the other hand, the cyclical position of the economy, the response of monetary policy and other elements of economic policy are also crucial. According to several studies, the multiplier is state-dependent, i.e. it changes during the cycle, can develop asymmetrically, and has non-linear characteristics (Auerbach Gorodnichenko 2012a and 2012b). During a prolonged recession, the fiscal shock may have a lasting effect due to hysteresis ${ }^{6}$ (DeLong - Summers 2012). Monetary policy can also contribute to the longer-term impact of fiscal policy if it does not offset fiscal expansion by raising interest rates. Thus, it can extend the effect of a two-year temporary impulse for five years according to DSGE models (Coenen et al. 2012). Fiscal policy often forms part of a broad macroeconomic programme and is difficult to separate from it. This is what happened in the two most cited cases of "expansionary fiscal consolidation" in Denmark and Ireland. ${ }^{7}$

As for the fiscal multiplier, the possible reasons for the differences in the empirical literature are of a substantive nature on the one hand, and a methodological nature on the other hand. The fact that the results vary from country to country causes

\footnotetext{
${ }^{6}$ While in the context of a non-sustainable recession the fiscal multiplier tends to zero, in a sustainable recession the longer-term multiplier may even exceed the short-term one (DeLong - Summers 2012).

${ }^{7}$ In both countries, there was substantial exchange rate depreciation, interest rates and inflation fell, capital flows were liberalised, and moderated wage dynamics also reduced export prices. Ireland has also undergone a structural labour market reform, and the EU and EMU memberships have also had a positive impact. On this basis, many economist (Eichengreen 1998, Prammer 2004, Barry 1991, Bradley - Whelan 1997) doubt the non-Keynesian nature of the Danish and Irish fiscal adjustments.
} 
a difference in content. This is not surprising, as there are significant differences in all important dimensions, such as economic development, openness, indebtedness, monetary policy and exchange rate regimes, and nominal and real rigidities. Significant discrepancies were found between developed and less developed countries based on the databases of OECD and World Bank (Giavazzi et al. 2000). Even within developed countries, there were results different in sign between the United States and the United Kingdom (Jones et al. 2015), which may be attributable to the unique characteristics of the United States. Based on these, a uniform fiscal recipe is not conceivable even for aggregate fiscal stabilisation (not to mention the composition of fiscal measures, which will be discussed in more detail in the last section).

A methodological problem is how the relationship between fiscal policy and other variables can be taken into account in the estimation. In the simulations performed based on the DSGE model (Coenen et al. 2012), detailed correlations between the variables, including microeconomic decisions as well, are dominant, but they cannot handle the state-dependent (asymmetric and non-linear) characteristics of the multipliers. Empirical estimates (regression, VAR, SVAR) are usually also linear, and thus the state-dependent nature can only be captured in special cases (Auerbach-Gorodnichenko 2012a and 2012b). Another methodological problem, which we will return to later, is that discretionary measures are often identified as a change in the cyclically-adjusted (primary) deficit, which leads to bias, as the impact of financial cycles is not eliminated. Exogenous fiscal shocks are not properly defined in this framework for other reasons as well. For example, Romer and Romer (2010) distinguish four types of reasons in the case of tax measures. The first two are endogenous (related to other effects on output), namely measures offsetting expenditure and other effects on output in the near future. By contrast, measures taken to reduce accumulated debt and achieve long-term goals can be considered exogenous measures. In order to define these latter measures, a narrative method based on the direct estimation of individual tax measures has been developed. This also draws the attention to another methodological problem, namely, the composition of the measures, i.e. what types of taxes and expenditures change. In their study 'Does "The" Fiscal Multiplier Exist?', Baksa et al. (2014) find that there is no single fiscal multiplier and that different forms of fiscal expansion (the forms examined: VAT, PIT, social contributions, financial transfers, public expenditure) have different multipliers. Model-based approaches generally agree that permanent changes in indirect taxes, transfers, and government consumption have only a shortterm effect on output, and this will also disappear within five years (Coenen et al. 2012). By contrast, a sustained change in public investment or corporate taxes can even have a lasting effect and may persist for over five years because it affects the capital stock of the economy (Coenen et al. 2012). If we consider a general demand increase, the weight of these more permanent items is much lower than that of short-term items, and therefore their impact will be determining. 


\section{Illustration of an unpleasant arithmetic}

In the following, we provide a simple illustration of the significance of multipliers. Figure 2 shows that government debt was very similar in the euro area and in the USA in 1995 and 2007, and the gap between them has been steadily increasing since then, similar to GDP. In the illustration, we examine how much the euro area's debt would be in a scenario where a general demand increasing fiscal policy would provide a steady 3 per cent growth rate between 1995 and 2019. A 3 per cent annual growth would close the gap between the USA and the euro area in 1995 and 2007, and after 2008, not only would the growth rate not diverge, but even a one-off decline in level in the USA would not occur. To achieve this fixed growth rate, the higher the deficit and debt growth are the smaller the multiplier must be and, conversely, a larger multiplier requires a less steep deficit expansion. To find out whether continuous aggregate expansion is a panacea or just a blame-shifting device, we performed simulations for both possible and impossible values of the multiplier.

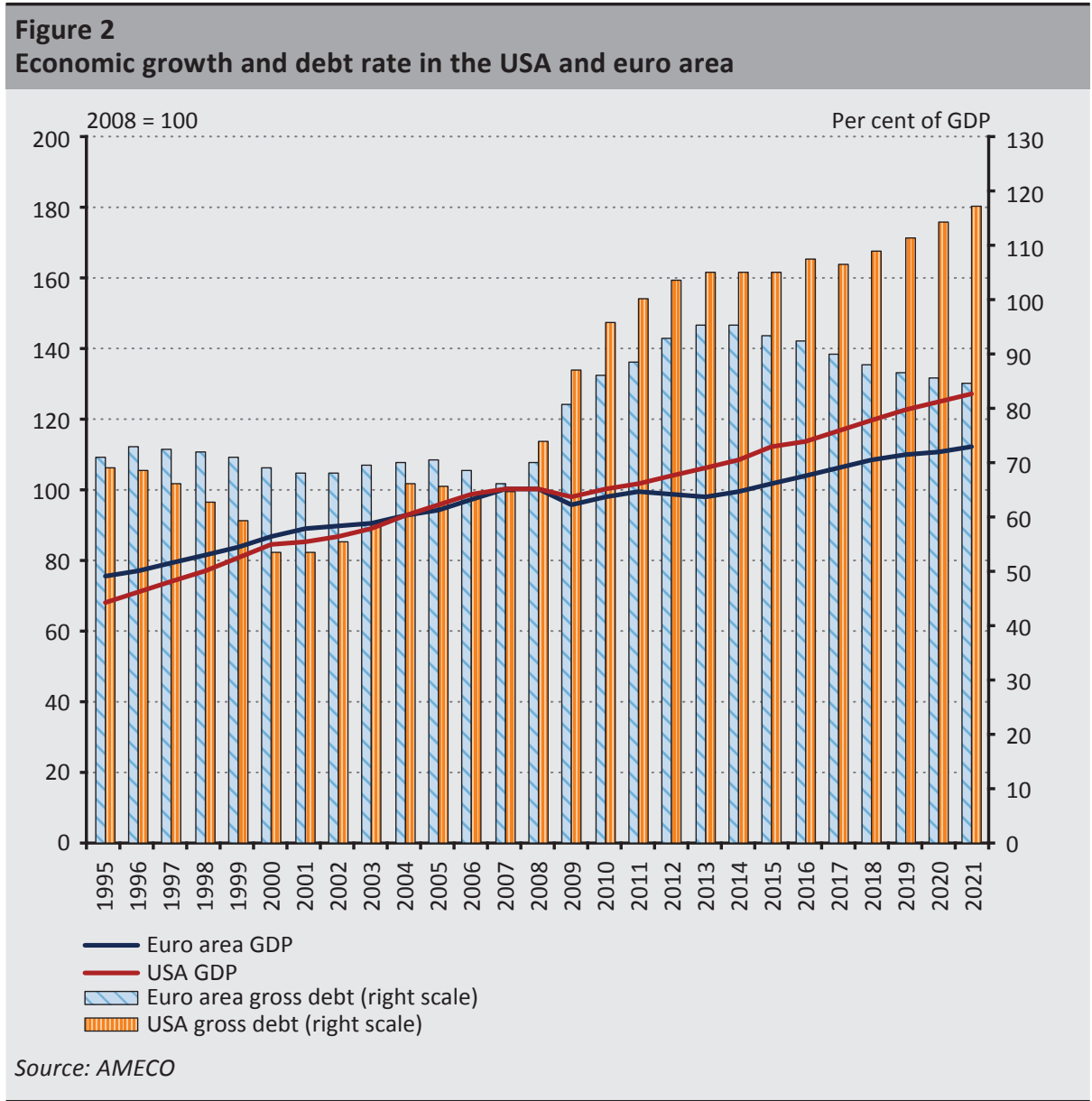


In the simulation, we made different assumptions, and if there was a choice, we opted for the more optimistic version, resulting in a lower debt ratio. One exception to this is the choice of multipliers, as our goal here is exactly to present the different scenarios. The baseline scenario is based on a New Keynesian effect, which has the following multipliers for five years: $0.5 ; 0.7 ; 0.5 ; 0.3 ; 0.1$; and then zero afterwards. We also calculated a variant corresponding to the neoclassical synthesis, which assumes a multiplier 0.1 lower than the previous one over the entire time horizon; thus, it can also be considered as a sensitivity analysis. The intuitive background of the multiplier's near-zero mid-term value is as follows: Given a nominal demand increase corresponding to 1 per cent of GDP, 37 per cent of this will return to the budget (this was the value of tax centralisation in the euro area in 2008). The net impulse is thus 0.63 , half of which appears, let us say, in the deflators (government consumption deflator, $\mathrm{CPI}$ ) and the other half in the real variables. In the case of an open economy, one-half of the real effect increases the production of real GDP, i.e. it is about 0.16 . Due to various compensatory mechanisms, this may be close to zero in the medium term.

In addition to these two trajectories, we also assumed a hysteresis scenario between 2009 and 2018, where the multiplier is 0.63 higher over the entire time horizon. In order to show the maximum possible growth and minimum debt ratio effect, we assumed for this entire period that the conditions for hysteresis may have been met. As the net impulse reduced by the tax-content is 0.63 , this multiplier value can be considered as a medium-term extreme value where the impulse applies 100 per cent, in other words, significant spillover through openness, neutralisation channels and deflator is offset fully and for a long period by positive effects on capital stock or unemployment (we also disregarded the limits of the latter). This is an optimistic assumption if we consider that this does not involve a targeted measure, but rather a general increase in demand, when actors who do not need it also benefit from the impulse, and thus their activity is not affected. For the purpose of a sensitivity analysis, we prepared an even more optimistic scenario, which can be considered extreme, where, from 2009 onwards, the multiplier was 1.7 higher than the baseline.

There is a medium-term multiplier where the expansion is self-financing, and this can be derived from the tax centralisation based on formula (13). Even if the effect of other variables (openness, marginal propensity to consume) may be offset by other factors, in terms of the deficit the amount of tax revenue that is recovered is what matters. This value is 2.7 for a 37 per cent tax centralisation, which is outside the range of multipliers that can be realistically considered. In this case, nominal debt does not change, but the debt ratio decreases due to higher GDP. Taking this effect into account, by ensuring an unchanged debt ratio, the self-financing medium-term multiplier is 2.55 .

If in the medium term a 1 per cent impulse does not result in almost three times the level of GDP, the recovery from tax will not be enough to be self-financing. In this 
case, the impulses of the individual years accumulate into deficits and the deficits into debt. As a result of the deficit, GDP is higher, but this can only moderate the increase in the debt ratio resulting from the accumulation of deficits. The result, as shown in the figure, is exponentially growing debt.

In the illustrative calculation, we added to the actual deficit and debt trajectory the increasing deficit which is required to maintain a steady growth rate of 3 per cent, ${ }^{8}$ i.e. the interest on accrued debt with the implicit interest rate calculated based on the actual interest payment and actual debt. Beyond a certain debt level, it becomes unrealistic, but we assume that the interest premium will not increase due to higher debt, which means that our calculation can be considered as an absolute lowerbound estimate of deficit and debt. The nominal debt thus obtained is adjusted by the difference between the actual GDP and the GDP obtained based on 3 per cent growth, as higher GDP ceteris paribus reduces the debt ratio.

\section{Figure 3}

Simulation of the debt ratio of the euro area for different multipliers

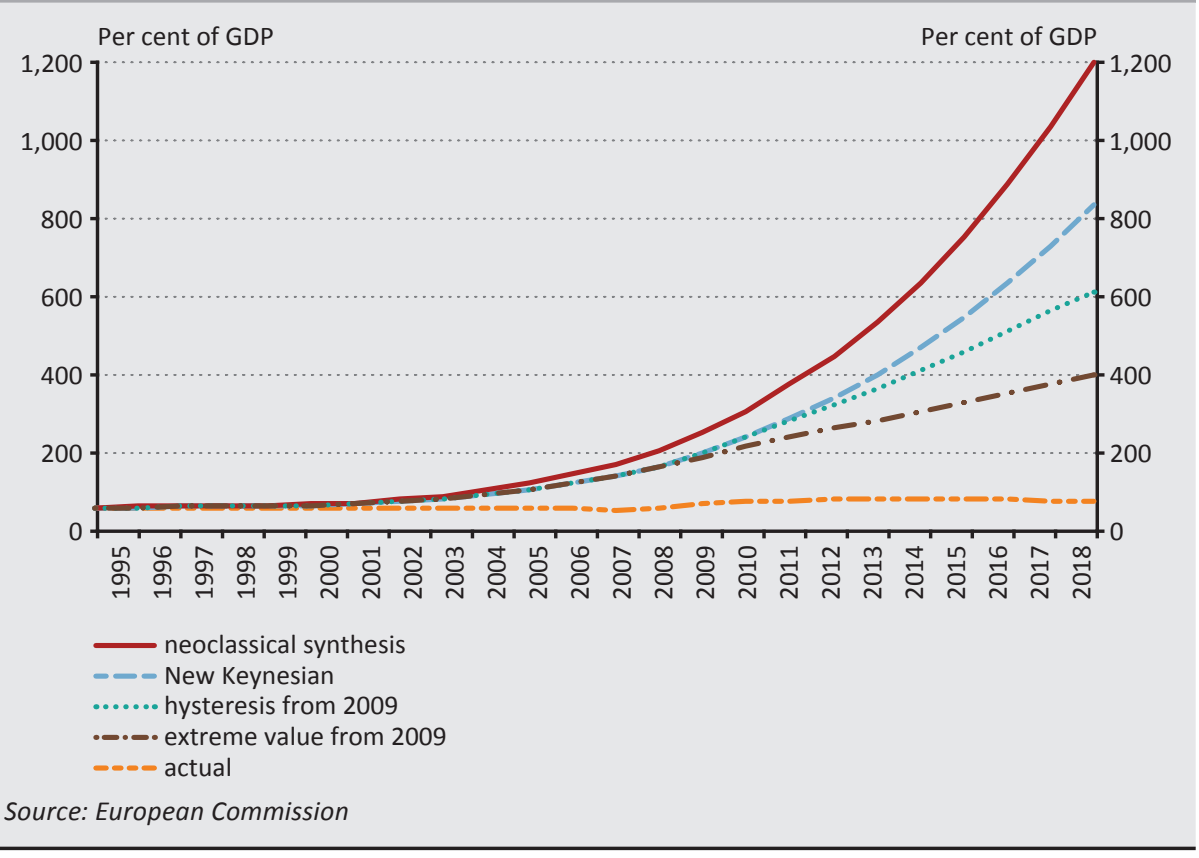

${ }^{8}$ Extent of required impulse:

$$
\text { expenditure }_{t}=\left\{1.03 \mathrm{gdp}_{t-1}-\left(1+\sum_{i=1996}^{t} \text { expenditur }_{i} \text { multiplier }_{t-i}\right)\right\} \frac{g d p_{t-1}}{\text { multiplier }_{0}},
$$

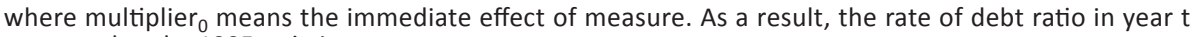
compared to the 1995 ratio is:

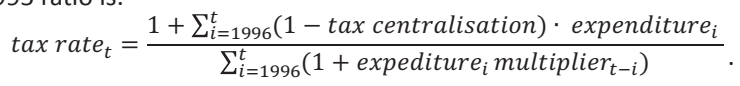


The results show that between 1995 and 2008, the debt ratio would have increased with a weak New Keynesian effect by 107 per cent of GDP (of which 9 percentage points is interest expenditure) compared to the actual data, and by 148 per cent (interest spending: 14 percentage points) for the neoclassical synthesis. In the hysteresis scenario, the change in the debt ratio between 2008 and 2018 is more than 442 percentage points (of which 72 percentage points are interest expenditures) and this exceeds, even at extreme values, the increase of 228 percentage points (of which 49 percentage points is interest spending). This shows that the costs of expansion outweigh the resulting benefits relatively quickly over time: in other words, sustained demand stimulation cannot be considered a panacea. The consensus on the optimal characteristics of a discretionary measure, which emphasises the temporary nature, is therefore founded.

On the basis of the illustrative calculation, it can be established that a substantial and general increase in demand for a long period of time would be restricted by costs significant even in the medium term, even if the Maastricht deficit and debt rules - which are sometimes considered too strict - did not exist. It should be noted that the EU's fiscal framework is much more complex than these two restrictions, making it more difficult to judge whether it sets appropriate stabilisation and sustainability targets, and applies adequate parameters to achieve them, and how it manages the potential trade-offs between objectives. During the continuous change of the framework, the role of the originally less important stock indicator (debt) increased in parallel with the strengthening of the sustainability aspect, and on the other hand, the effectiveness of the stabilisation function required a stronger emphasis on the structural balance target (medium-term objective, MTO). The MTO set for each Member State provides a sufficient safety margin against breaching the Maastricht 3 per cent threshold in the case of normal (non-exceptional) cyclical fluctuations. ${ }^{9}$ Whereas previously the consistency of the thresholds of Maastricht deficit ratio and debt ratio has been examined, today the MTO can be compared as the threshold of a practical target close to zero and the debt. Based on this, the current trend of lower nominal GDP growth is also sufficient to stabilise the debt ratio at the threshold (cf. Lehmann et al. 2020: Figure 3).

\section{Automatic stabilisers and discretionary fiscal measures}

The effect of automatic stabilisers is not spectacular, and regarding this, the principle of "letting automatic stabilisers operate" was formulated. In other words, this means that, offsetting measures should not be taken. Fiscal policy makers, mutatis mutandis, focus on the latter, on the specific discretionary measures.

\footnotetext{
${ }^{9}$ In addition, the occurrence of an exceptional event or a lasting and severe economic downturn means an exemption for the Member State. This was defined as a negative growth rate or as an accumulated loss of output during a protracted period of very low real growth of GDP relative to its potential.
} 
However, with the exception of the narrative method, which focuses on individual measures, other analyses and research identify the change in the cyclicallyadjusted (primary) balance as an estimate of the overall amount of a discretionary measure. On the one hand, there is a conceptual problem with this approach, since by eliminating the cyclical component, automatic stabilisers are omitted, which in turn do have an effect (otherwise they would not make sense). On the other hand, from a methodological point of view, there have been a number of criticisms of the cyclical adjustment, including that it only partially eliminates the impact of the financial cycle. Thus, the uneliminated part is included in the category of "discretionary measure" on a residual basis, thereby causing systematic bias in estimating the impact of fiscal policy (Guajardo et al. 2011).

Next, we first address automatic stabilisers and then discuss why the cyclicallyadjusted (primary) balance is not a good approximation to discretionary fiscal action in methodological terms.

For the sake of simplicity, formula (6) assumed that the tax system was not progressive. In the case of progressive tax systems that can be observed in reality, high marginal tax rates reduce the multiplier effect and thereby the sensitivity of the economy to shocks. Musgrave (1959) called this function of the progressive tax system "built-in stabilisers". According to a narrower definition in this sense, the effect of automatic stabilisers is such that unemployment benefits $(U)$ and progressive taxes $(T)$ follow automatically and to an extent more than equiproportional the fluctuations in economic performance (GDP) (the balance of these two items is $T^{*}=T-U$ ). The ability to stabilise varies over time as the trends in the tax system, social benefits and demography change (Duesenberry et al. 1960). It is important to note that taxes and benefits do not directly follow the development of GDP, but the development of tax bases and unemployment. Most of all these (e.g. personal taxes and contributions) follow the decline in GDP with a time lag if the decline is caused by a shock due to external demand or investment. Thus, the effect of automatic stabilisers in a narrow sense occurs with the right timing, which occurs mostly through changes in the disposable income of the population. In addition to this effect, the redistribution channel may also play a role, because if the income of households that spend their expenditures increases on account of taxpayer/saving households, aggregate demand will increase even more (Blinder 1975). Moreover, progressive personal taxes also have an incentive effect on labour supply that ensures stabilisation (Christiano 1984).

From among the above three channels, we now address the crucial question of the potential impact of automatic stabilisers in a narrow sense exerted through aggregate demand. 
Let the elasticity of tax revenue be $\varepsilon$, that is $\varepsilon=\frac{\Delta T}{T_{-1}^{*}}: \frac{\Delta Y}{Y_{-1}}$ and thus formula (12) can be transformed:

$$
\frac{F I}{Y_{-1}}=\left(\frac{\Delta G}{G_{-1}}-n\right) \frac{G_{-1}}{Y_{-1}}-(\varepsilon-1) \frac{\Delta Y}{Y_{-1}} \frac{T_{-1}^{*}}{Y_{-1}} .
$$

According to the narrow definition of automatic stabilisers, this impulse is equal to the extent to which these items follow the fluctuation of GDP by more than one unit $(\varepsilon-1)$.

Considering the EU as a whole, the official estimate of the specific (for a 1 per cent change in GDP) fiscal impulse provided by narrow automatic stabilisers is currently 0.229 , of which the effect of tax progressivity is 0.171 and unemployment benefit is $0.057 . .^{10}$

Let us turn now to the full definition of automatic stabilisers. This includes the effect of all revenue and expenditure except interest expenses. This is explained by the fact that neutral fiscal policy also has an automatic stabilising effect. If we deduct from the primary balance tax revenue and unemployment expenditure which are affected by the cycle, then we obtain non-tax revenue and primary expenditure without unemployment benefits. These are increased by the government in a discretionary manner, in neutral cases at the rate of potential/trend GDP growth. ${ }^{11}$ It can be deduced that the cyclical component is equal to the full automatic stabilising effect if the primary balance is zero. ${ }^{12}$ This is broadly true at the EU level, and thus in principle the cyclical component could be very close to the automatic stabiliser effect. ${ }^{13}$ According to official estimates for the EU, 1 per cent shift in GDP changes the cyclical component by 0.537 percentage points (Mourre et al. 2019). However, this cannot be considered appropriate for two reasons. On the one hand, it does not take for a basis the primary balance items because it does not adjust for interest expenditure. On the other hand, taxes should be identified with the taxes of the private sector (Jedrzejowicz et al. 2009). This not only reduces the cyclical component, as due to the parallel adjustment for taxes and expenditures the effect for narrower stabilisers (formula (14)) and the overall stabilisation effect for expenditure will be concurrently smaller. This means that the specific stabiliser effect at the EU level may not be the officially estimated 0.537 , but about 0.450 ,

\footnotetext{
${ }^{10}$ Based on tables in Part I of the Appendix, Mourre et al. (2019)

${ }^{11}$ In the case of taxes, there are not only rates, but also a number of other parameters, the change in which can be considered as a measure. In this framework, the annual valorisation of the nominal elements of the tax system (bands, ceilings, etc.) presents a problem. In a neutral case, although valorisation takes place, this is not a measure, as the tax burden does not change due to this. However, the lack of valorisation is a tax burden increasing measure.

12 P. Kiss (2011:30): Box 5: "The fiscal impact of the cycle vs. the stabilising effect of fiscal policy"

${ }^{13}$ The EU had a primary surplus of just over 1 per cent of GDP in 2018, representing a minimal bias compared to the assumption of a balanced budget.
} 
i.e. in the case of a shock of 1 per cent of GDP, public finances will offset 45 per cent: ${ }^{14}$ on the one hand, netting against public taxes affects the estimated extent of narrow automatic stabilisers (0.229), reducing its specific rate to about 0.190 , while on the other hand, neutral items also netted against taxes explain the 0.260 value remaining from 0.450 .

So far, we have assumed that cyclical adjustment properly eliminates the impact of different cyclical fluctuations on revenues. However, this is not the case for methodological reasons, because, after performing the cyclical adjustment, a substantial and volatile unexplainable part remains (Morris et al. 2009). ${ }^{15}$ Even in the case of the USA it can be shown that cyclical adjustment does not address the effect of asset price volatility (CBO 2013). Asset prices also have a distorting effect at the level of OECD countries (Price - Dang 2011). All these can cause systematic bias in estimating the impact of fiscal policy (Guajardo et al. 2011). This is because the positive effect of asset prices was not eliminated by the cyclical adjustment, and thus it seemed to be a balance-improving measure if - in order to determine the measure - an analysis took as a basis a change in the cyclically-adjusted primary balance (as most did). If the increase in asset prices was followed by an increase in output, a correlation could be found between the apparent balance improvement and the increase. In this situation, traditional methods of cyclical adjustment could have been replaced by the "finance-neutral" output gap method (Borio et al. 2013). Namely, traditional "inflation-neutral" methods, due to several factors, such as the distortion of the Phillips curve, do not work reliably in a lowinflation environment. A methodology is proposed that can be evaluated even in a low inflation environment and results in low-revision data. The authors received much more accurate data for the historical data of the USA and other countries than the OECD and the International Monetary Fund had previously received. Prior to the global economic crisis, real-time data showed that the economies of the USA, the UK and Spain were characterised by a negative or at most a closed output gap, depending on the methodology chosen, but ex post reviews pointed out the shortcomings of traditional methodologies. The model developed by Borio et al. (2013), which also takes into account the build-up of financial cycles through increases in real estate prices and credit aggregates, shows a substantial positive output gap considering both real-time data and the retrospective method. In addition, the degree of ex-post revision is reduced to a minimum. According to their estimate, while business cycles last at most for 8 years, financial cycles typically

\footnotetext{
${ }^{14}$ At the EU level, tax and contribution revenues account for 33 per cent of GDP, one-quarter to one-fifth of which may stem from public spending.

${ }^{15}$ Profit taxes caused extra tax revenue (windfall) in 1999-2000 and 2004-2007, and extra tax loss (shortfall) in 2001-2003 in Germany, Spain, France, Italy and the Netherlands. This was due, in addition to loss relief, to revaluation gains. Cyclical adjustment does not cover housing investment, and thus only the cycle of consumption has been eliminated from indirect taxes. This caused unexplained residuals in Ireland and Spain.
} 
alternate every 16 to 20 years. Building on the results of the research by Borio et al. (2013), Bernhofer et al. (2014) also found that traditional (inflation-neutral) methods of the output gap cannot signal recovery due to financial cycles. A novelty compared to previous research is that the authors also set apart in the model the trend and cyclical change in GDP, and examine two groups of countries, one developing and one developed. Calculating using the new methodology, the cyclical component of GDP was much higher for most countries in the pre-crisis period than the value of the cyclical component calculated using traditional methods. Depending on the country, real output - which is substantially higher than potential - was the result of rising real estate prices, rising lending activity, or a combination of these two factors. In the next section, we present the consequences of a biased estimate of the output gap.

\section{Real time uncertainty of potential/trend GDP}

We have seen that the equilibrium parameter $n$ is a determining factor of formula (10) and thus a key element of the overall definition of automatic stabilisers as well as the discretionary measure defined relative to the neutral path calculated in this way.

Several studies (Forni - Momigliano 2004, Cimadomo 2008, Borio et al. 2013, Bernhofer et al. 2014) have shown that the estimation of the output gap in real time, i.e. when fiscal policy decisions were made, differed significantly from what could be estimated based on subsequent developments. Subsequent revisions of the output gap stemmed from the fact that the estimation of potential growth subsequently worsened, and thus an output gap that previously seemed to be positive turned out to be negative in retrospect (Table 1). As a consequence, in many countries, fiscal policy intended to be counter-cyclical between 1994 and 2006 was subsequently proven to be pro-cyclical (Caudal et al. 2013, Forni - Momigliano 2004, Cimadomo 2008, P. Kiss 2017). The estimate of potential GDP before the crisis may have been distorted upwards by the emergence of the financial cycle in addition to business cycles (Borio et al. 2013, Bernhofer et al. 2014). Rogoff (2016) points out that, as a consequence of the financial cycle, the size of housing bubble accompanied by leverage and its bursting, as well as the extent of pre- and post-crisis asset price changes were significant. In addition to Boone and Buti (2019), Benoît Cœuré (2017) also points out that the downward revision of the estimate for potential GDP has a trend regardless of the phenomenon of hysteresis. ${ }^{16}$

\footnotetext{
16 "These effects have been taken by many as evidence for hysteresis. But the discussion is arguably more complex than this. For sure, potential output estimates are chronically unreliable and often subject to substantial revisions ex post. [...] P(p)otential output growth had been slowing in the euro area well before the crisis, mainly reflecting a long-term slowdown in total factor productivity (TFP)." (Cœuré 2017)
} 
Table 1

Estimate of the output gap for a given year in the previous year and in 2019 (as a percentage of GDP)

\begin{tabular}{l|c|c|c|c|c|c|c|c} 
YEAR & \multicolumn{2}{|c|}{$\mathbf{2 0 0 0}$} & \multicolumn{2}{c|}{$\mathbf{2 0 0 1}$} & \multicolumn{2}{c}{$\mathbf{2 0 0 2}$} & \multicolumn{2}{c}{$\mathbf{2 0 0 3}$} \\
\hline Publication & $\mathbf{1 9 9 9}$ & $\mathbf{2 0 1 9}$ & $\mathbf{2 0 0 0}$ & $\mathbf{2 0 1 9}$ & $\mathbf{2 0 0 1}$ & $\mathbf{2 0 1 9}$ & $\mathbf{2 0 0 2}$ & $\mathbf{2 0 1 9}$ \\
\hline Austria & 0,6 & 1,6 & $-0,5$ & 0,4 & $-1,1$ & $-0,1$ & $-0,4$ & $-1,3$ \\
\hline Belgium & $-2,0$ & 1,8 & 0,8 & 0,5 & $-0,3$ & 0,0 & $-0,4$ & $-1,0$ \\
\hline Denmark & $-2,9$ & 2,7 & 0,0 & 1,4 & 0,4 & 0,2 & $-0,1$ & $-0,7$ \\
\hline Finland & $-2,2$ & 2,9 & 1,0 & 1,3 & 1,8 & $-0,4$ & $-0,3$ & $-1,6$ \\
\hline France & $-2,7$ & 2,2 & 1,8 & 2,2 & $-0,6$ & 1,6 & $-0,3$ & 0,7 \\
\hline Germany & $-0,1$ & 1,4 & $-0,1$ & 1,7 & $-1,5$ & 0,3 & $-1,4$ & $-1,6$ \\
\hline Greece & $-0,2$ & 1,3 & 1,3 & 1,3 & 2,2 & 1,2 & 1,8 & 2,2 \\
\hline Ireland & 0,3 & 4,5 & 1,5 & 2,2 & 0,2 & 1,4 & $-1,4$ & $-1,2$ \\
\hline Italy & $-2,3$ & 1,9 & $-2,4$ & 2,4 & $-0,9$ & 1,5 & $-1,3$ & 0,7 \\
\hline Luxemburg & $-2,1$ & 5,9 & $-1,1$ & 3,4 & $-3,0$ & 2,9 & 0,0 & 0,3 \\
\hline Netherlands & $-3,3$ & 2,4 & 2,0 & 1,6 & $-1,1$ & $-0,6$ & $-1,8$ & $-2,4$ \\
\hline Portugal & 0,1 & 3,0 & $-1,0$ & 2,1 & $-1,5$ & 0,8 & $-2,8$ & $-1,5$ \\
\hline Spain & $-3,2$ & 3,0 & 0,1 & 3,5 & $-0,9$ & 2,9 & $-1,5$ & 2,3 \\
\hline Sweden & $-0,9$ & 1,7 & 0,3 & 0,0 & 0,7 & $-0,8$ & $-0,1$ & $-1,4$ \\
\hline United Kingdom & $-0,8$ & 1,1 & 1,2 & 0,9 & $-1,0$ & 0,2 & $-0,9$ & 0,7 \\
\hline
\end{tabular}

Note: Blue colour: the sign was estimated right, red colour: even the sign was not estimated right. Source: EC (1999, 2000, 2001, 2002) és AMECO

Figure 4 illustrates the problem caused by real-time uncertainty of the output gap in shaping the right direction of fiscal policy, even if the goal would be to "let automatic stabilisers operate". In the figure, real-time no-policy-change growth in expenditure is in line with the trend in tax revenues, which, in the absence of measures, follows the pace of economic growth. ${ }^{17}$ If, after a significant downturn, it subsequently turns out that the trend in growth and thus tax revenues needs to be corrected downward (dashed blue line), the consistent neutral expenditure path (dashed green line) will also change. It only then becomes apparent that the expenditure intended to be neutral was expansive throughout; the cumulative rate of expansion is the difference between the dashed and full green lines (contrary to the intention, the automatic stabilisers were not allowed to operate). The higher cyclically-adjusted deficit in this case indicates that expenditure is higher than the neutral level and will therefore need to be adjusted at some point, preferably not during the crisis. If further counter-cyclical expansion measures are taken during the crisis, this adjustment deferred to the time of recovery will be even greater.

${ }^{17}$ For the definition of discretionary expenditure, the definition of neutral expenditure growth is required as a benchmark. The actual spending path can thus at all times be split into a neutral and discretionary part. 
Here, however, as mentioned in the introduction, in the case of a high debt ratio, the sustainability aspect may conflict with the stabilisation function.

\section{Figure 4 \\ Effect of downward revision of the growth trend on revenues and expenditure}

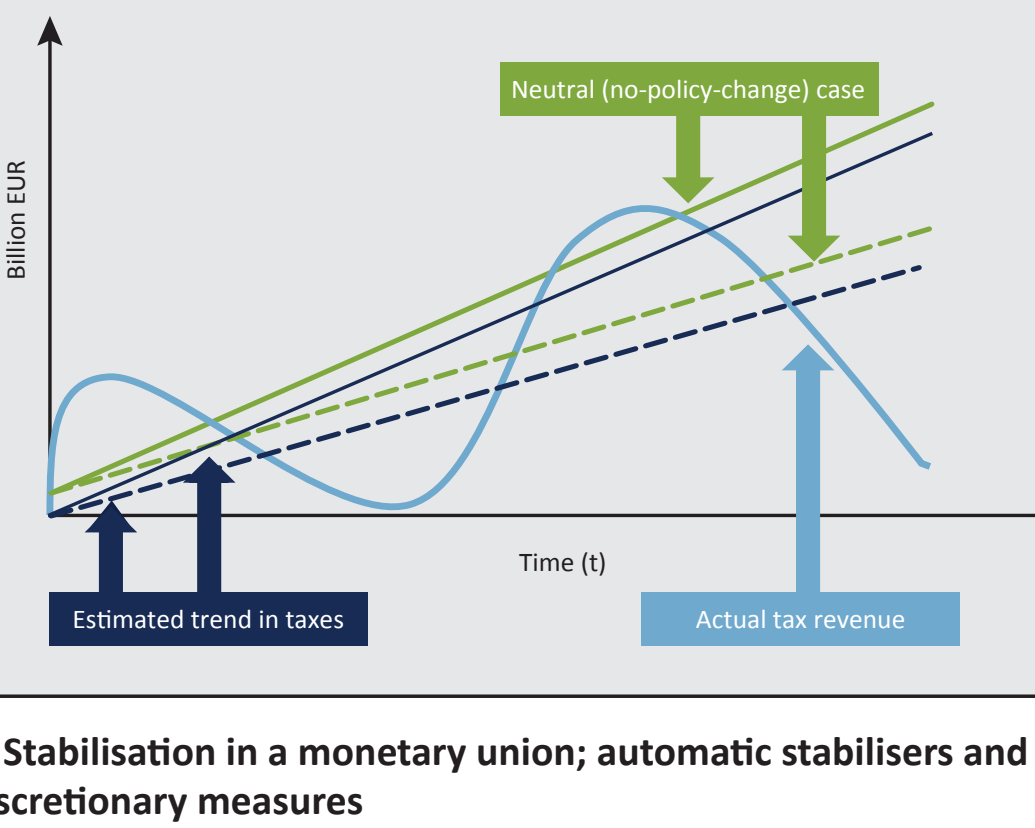

The member states of a monetary union have their own fiscal policy to stabilise their economies, as exchange rate adjustment within the monetary union is no longer possible and the correction of relative prices is a slower process. In the case of individual negative shocks impacting individual countries, the distribution of risk within the monetary union can also contribute to stabilisation. One element of this is to weaken the link between local income and consumption through an integrated capital market, and the other is to break the link between local credit supply and the capital of local banks through the integration of the banking sector. These two factors neutralise 70 per cent of local shocks in the United States, while only neutralising 25 per cent in the euro area (Nikolov 2016). In the past, there has even been pro-cyclicality in the euro area, resulting in lending across countries in good times and repayment in bad times (Albertazzi - Botero 2014). The Five Presidents' Report (Juncker et al. 2015) therefore identified the completion of a Financial Union as a second objective in time, as part of which a single bank supervision, a single bank resolution (Single Resolution Fund, Single Resolution Mechanism), a single deposit insurance (European Deposit Insurance Scheme) and a Capital Markets 
Union can be created. Macroprudential policy is also important because, if properly targeted, it can reduce the side effects of low interest rates (Draghi 2019).

Compared to the potential stabilising effect of these factors, the significance of fiscal transfers between Member States may be much less. Even in countries establishing significant fiscal federalism, such as the United States, only 10 per cent of shocks are neutralised by fiscal transfers provided to states (Nikolov 2016). Dreyer and Schmid (2015) showed that the level of stabilisation and redistribution similar to the USA's system would require a much larger transfer between euro area countries. The Five President's Report (Juncker et al. 2015) set the completion of a Fiscal Union as the third goal in time. An instrument, called automatic stabilisation, would be introduced in the euro area, which does not aim to stabilise the euro area as a whole, but to mitigate the effects of shocks in general. However, this should not lead to permanent, one-way transfers between countries, as it cannot not be conceived as a way to equalise incomes between Member States. It would not replace the European Stability Mechanism (ESM), which remains a crisis management instrument, but would prevent its use. Proposals made since then would use transfers between governments. Member States would contribute to a fund from which they can automatically receive a transfer depending on the development of their macroeconomic variables. Proposals differ in terms of the use of resources: some would give transfers to households (unemployment benefits) and some would spend it on public investment. The former could respond immediately to an economic downturn, that is, it could channel funds to households in parallel with rising unemployment. The latter can only react to a downturn with a delay, as the measurement of economic indicators may be deferred in time and the preparation of public investments may be a protracted process.

According to the definitions in Section 4, only unemployment benefits can be classified as an automatic stabiliser, while the other as a discretionary measure. In the narrow sense, a progressive tax system and unemployment benefits, and in a more broad sense, expenditure growth kept stable represent an automatic stabiliser, the latter element would neutralise shocks to the euro area as a whole, and not to shocks at the level of the individual Member States.

On the revenue side, the EU's common budget is not progressive and does not automatically follow the cycle, ${ }^{18}$ while structural transfers - which account for the majority of expenditure - are not smooth. They fluctuate corresponding to the seven-year programming periods, and thus whether or not they correspond to a discretionary measure with a counter-cyclical or pro-cyclical effect is random. The

${ }^{18}$ However, based on the development of GNI in the previous year, corrections are applied to Member States' contributions. 
size of the common budget is around 1 per cent of EU GDP; therefore, at present, it cannot be considered a stabilising factor either in principle or in practice.

Let us do a simple thought experiment about what might change in the future: On the one hand, the common budget could centralise the Member States' existing expenditure (together with the revenue covering the same). The largest items of the Member States are administration, education, health, pensions, unemployment and family benefits, and corporate subsidies. Centralisation of any of these items is not justified. Centralisation of defence expenditures is not realistic either, but in this regard a minimal amount is conceivable. In the case of environmental and R\&D subsidies, partial centralisation cannot be ruled out, but the total amount would realistically remain below 1 per cent of GDP. On the other hand, the common budget could find additional expenditure, but this would also require additional funds, i.e. taxes at EU level would need to be increased for that.$^{19}$ Continuing the thought experiment, these expenditures could be the previously mentioned stabilisation subsidies, for which perhaps an amount of around 1 per cent of GDP might be enough. Overall, the common budget would increase to a maximum of 3 per cent of GDP, of which stable expenditures would total 1 per cent of GDP, another 1 per cent would fluctuate in line with the seven-year programming period, and the additional 1 per cent stabilisation support could be counter-cyclical. Accordingly, while at the level of EU Member States a specific stabilising effect of 0.537 can be estimated for a 1 per cent decline (see Section 4), the stabilising effect of the 1 per cent counter-cyclical part of the common budget would be 0.010 . Thus, the result of our thought experiment would apparently have no considerable stabilising role. However, a discretionary stabilisation expenditure of 1 per cent at EU level could cover counter-cyclical measures of up to $4-5$ per cent of GDP at the level of countries receiving support.

\section{Fiscal policy coordination and structural reforms}

So far, we addressed the aggregate stabilisation policy that is implemented through a general increase or reduction of demand. In the following, we discuss targeted measures, including the special case where they are implemented in a balanceneutral manner by changing the revenue-expenditure structure. Targeted measures can be linked also to structural reforms, which will also be addressed.

By way of introduction, we examine the issue of coordination. The aim of the European Semester was to strengthen economic policy coordination between Member States, but as the Five Presidents' Report (Juncker et al. 2015) pointed

\footnotetext{
${ }^{19}$ A common European unemployment benefit system, which would complement national unemployment benefit systems, could work well in terms of stabilisation, but could lead to distortions at the level of Member States operating different systems. Not only the additional amounts would be different in proportions, but the duration of the benefit could also vary significantly.
} 
out, many regulations and procedures were too complex and not efficient enough. The recommendations should be directed at the structural reforms required to improve the efficiency of the single market and to increase potential economic growth. The importance of the government balance and the aggregate stabilisation policy implemented through its change is thus diminishing for several reasons. In addition to structural reforms, the composition of fiscal policy becomes increasingly important, and within the framework of Macroeconomic Imbalance Procedure aspects, such as the prevention of real estate bubbles and the early detection of declining competitiveness, the rising private and public debt and underinvestment emerge, which may require targeted reforms.

It is important to identify the causes, as, for example, specific steps depend on the factors behind an economic downturn. The Magyar Nemzeti Bank's 2015 Growth Report (MNB 2015) reviewed the potential causes of the crisis. Of these, financial factors typically exert a temporary, albeit prolonged, effect on economic growth. To mitigate these problems, general or targeted demand increase may be required (Table 2).

\section{Table 2}

Fiscal reaction to cyclical problems in the economy

\begin{tabular}{l|l}
\multicolumn{1}{c|}{ Balance sheet crisis } & \multicolumn{1}{c}{ Counter-cyclical fiscal policy } \\
\hline $\begin{array}{l}\text { possible financial causes: } \\
\text { - rise in lending }\end{array}$ & $\begin{array}{l}\text { possible fiscal measures: } \\
\text { - excessive indebtedness }\end{array}$ \\
- balance sheet adjustments & $\begin{array}{l}\text { - targeted demand increase: } \\
\text { - capital transfers } \\
\text { - sectoral re-allocation }\end{array}$ \\
\hline \multicolumn{2}{l}{ Source: Based on MNB (2015) }
\end{tabular}

The 2015 Growth Report also drew attention to the fact that persistent real economy-related problems may also be the causes of the crisis. Table 3 summarises the possible causes and the targeted measures suitable for addressing them.

\section{Table 3}

Fiscal reaction to persistent stagnation

\begin{tabular}{l|l}
\multicolumn{1}{c|}{ Persistent stagnation } & \multicolumn{1}{c}{ Permanent fiscal reforms } \\
\hline possible real economy-related causes: & $\begin{array}{l}\text { possible fiscal measures: } \\
\text { - adverse demography }\end{array}$ \\
- insufficient innovation & - public intervention, support \\
- reduced investment & - support for public investments and private \\
- the weight of less productive services sector & $\begin{array}{l}\text { investments } \\
\text { increases }\end{array}$ \\
- the weight of salaries and wages decrease, & - income re-distribution \\
inequalities increase & \\
\hline Source: Based on MNB (2015) & \\
\hline
\end{tabular}


As part of the coordination, the EU Macroeconomic Imbalance Procedure (MIP) addresses, inter alia, the position of sectors and the problematic extent of trade surpluses (EC 2016). However, in order to explore the reasons, they look beyond mere identities in their analyses, thus making, for example, a distinction between Germany and Sweden. ${ }^{20}$

At the euro area level, reducing the natural rate of inflation is a common challenge with the same causes and consequences, which also requires coordination between countries. As Draghi (2019) puts it, monetary policy takes the natural rate of inflation for granted, and therefore, a low rate may also be raised by fiscal and structural policy. Structural policy can accelerate changes in resource allocation and innovation, which increases TFP. It is the composition of fiscal policy that matters: spending on education and efficient public investment increases productivity, and some measures reduce income inequalities and increase employment. According to estimates, all of this can prevent a decline in the natural rate of inflation (Rachel - Summers 2019). The share of productive expenditure (infrastructure investment, $R \& D$ and education) has declined in almost all euro area countries since the crisis (EFB 2019). According to ECB estimates, a coordinated investment expenditure would have six times the spill-over effect on the euro area if the central bank did not raise interest rates in response (Alloza et al.2019).

Both EU budgetary rules and the Macroeconomic Imbalance Procedure gives a prominent role to stock variables. In the event of a crisis, the problem may arise that there is no room for budgetary manoeuvre in the narrower sense that the debt (and deficit) cannot be increased. In the case of a sustainability problem, there is no possibility for a deficit-increasing, counter-cyclical fiscal policy, and even deficit-reducing measures may be required. However, this is when the importance of the details (targeting/effectiveness) become evident in the most obvious way. According to the most common definition of the room for manoeuvre (Heller 2005), the intended expenditure-increasing or tax-reducing measures cannot be implemented only at the expense of the deficit/debt. Their sources can be tax increases (e.g. tax shift), improving the efficiency of tax collection, reducing low priority expenditures, seigniorage revenues or foreign (e.g. EU) transfers. The case of aggregate stabilisation policy and targeted measures, and within that the balanceneutral reforms, can be contrasted.

One view is that in times of permanently low demand, general demand expansion is a good instrument; due to their costs, it is not worth choosing structural reforms. There is a risk of expansion if debt is high, but this will change in times of more

\footnotetext{
${ }^{20}$ In 2014, there was a significant foreign trade surplus of similar amount in both countries. In Sweden, however, the net international investment position was more balanced than in Germany, and thus in the latter case the current account surplus was classified as a macroeconomic imbalance, in contrast to the former case.
} 
severe crisis. In such cases, it may be true that the inclusion of indebted countries in coordinated expansion within a monetary union has a negative effect on the benefits side, and an even greater negative effect on the costs side, i.e. the cost of excluding them is higher than the cost of their inclusion. It is estimated that, as a result of these two effects, excluding them would reduce the positive annual impact on GDP by two-thirds (Triggs 2018). By contrast, structural reforms that reduce inflation may have short-term economic costs during a crisis, as they cannot be offset by monetary policy during times of ZLB (zero lower bound) (Eggertsson et al. 2014)

According to another view, during times of persistently low demand, more targeted measures are needed, in a balance-neutral manner, where appropriate, and structural reforms should also be prioritised (OECD 2016, Boone-Buti 2019). On the one hand, investment in infrastructure that is in line with the EU fiscal framework (OECD 2016, Boone - Buti 2019) can be effective, and on the other hand, growthenhancing fiscal reforms are needed that can have even short-term positive effects, such as housing subsidies, promotion of job search across regions and professions, or the removal of barriers to entry in the services sector (OECD 2016, OECD 2019b).

Finally, countries with little room for manoeuvre in terms of deficits can implement low-cost reforms (OECD 2016) or even balance-neutral fiscal measures in a way that these would only change the composition of taxes and the structure of expenditures while keeping the deficit unchanged. This is consistent with the observation that the multiplier of different discretionary measures is very different. Simulations of the French central bank's multi-country DSGE model show that boosting investments with less distortionary taxes raises both short- and long-term growth and thereby improves sustainability. They also found that the spill-over effect of balance-neutral reforms across countries is not large, but if coordinated and monetary policy does not respond, the impact may increase (Bussière et al. 2017).

Model calculations are also available for the effect of the balance-neutral Hungarian measures after 2010. The tax reform included a reduction in labour taxes, family tax allowances serving family policy purposes and a tax cut aimed at supporting businesses. By raising consumption taxes and imposing crisis taxes on the financial, retail, telecommunications and energy sectors, taxes were shifted away from production to consumption. The tax cut was partially offset on the expenditure side. Sick pay, early-retirement and disability pensions were reduced. The fact that - instead of unemployment benefits - job opportunities were provided also contributed to the increase in labour market activity. ${ }^{21}$ It is estimated that tax reduction and tax increase measures will have a positive impact on the economy in

${ }^{21}$ After 2010, the number of employees increased by some 740,000 , thus bringing the employment rate close to the EU average. 
the longer-term horizon (Palotai 2017, Baksay-Csomós 2014). Another simulation, examining larger tax measures and transfer changes (Szoboszlai et al. 2018) found that the introduction of a 16 per cent PIT increased effective labour supply by 3 per cent in the long term, largely due to intensive side adjustment and 0.6 per cent to employment increase. As a consequence, the negative budgetary impact could be reduced to one-fifth in the long term. The removal of the super-gross tax base (including employer's contribution) reduced the tax burden to a similar extent. This measure could in the long-term increase employment by 1.5 per cent, and thus the immediate negative impact on the deficit could be reduced to two-thirds in this case. Larger tax and transfer measures between 2008 and 2013 were examined by Benczúr et al. (2018). Between 2008 and 2010, they found that long-term GDP and employment could have increased, but without intensive side adjustment. By contrast, intensive side adjustment may have had a substantial positive effect between 2010 and 2013, but they linked the employment increase more to declining unemployment benefits.

For the euro area as a whole, according to the estimate of OECD, the TFP's contribution to potential growth was 0.2 per cent lower between 2007 and 2017 than in the pre-crisis period. Therefore, measures were proposed that would increase the TFP by 0.2 per cent per year for five years, and thereafter, the 1 per cent higher level would remain constant. Figure 5 shows how these structural measures and coordinated fiscal policy in the euro area would affect GDP based on the results of the OECD's estimation using the NiGEM model. This shows a deviation from the baseline in terms of level and it is visible that the effectiveness of fiscal policy in the narrow sense is insignificant and temporary compared to structural policy (OECD 2019: Box 1.4.). 


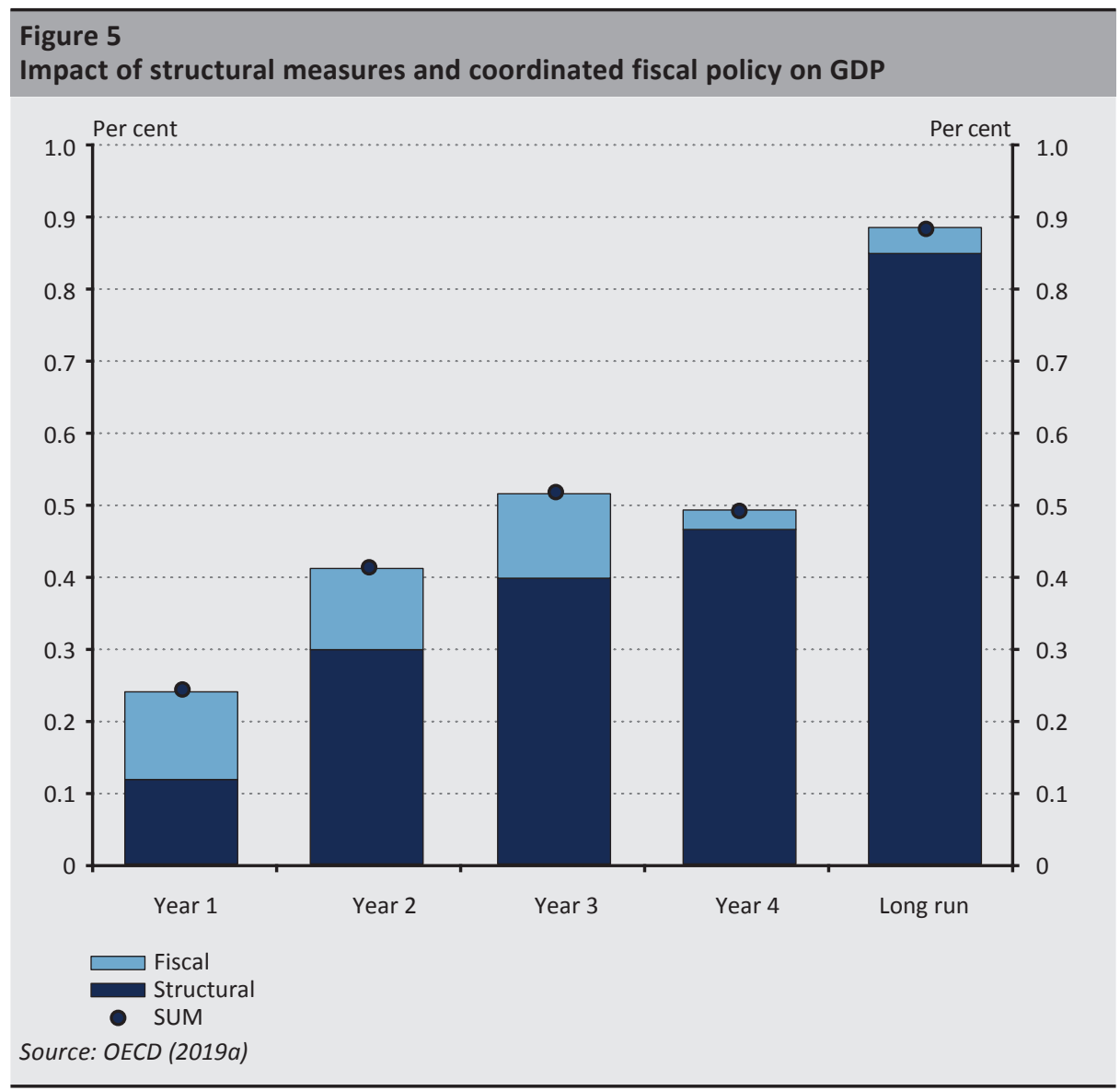

\section{Conclusions}

Previously, the two pillars of economic policy were considered to be monetary policy with traditional instruments and aggregate fiscal demand increase. After the crisis, not only the scope of monetary policy instruments expanded, but new pillars also emerged, and not only at the national level but also in the scope of coordination within the EU and the euro area. In addition to the function of stabilisation, there is also a need to increase potential economic growth and the efficiency of the single market. All of these objectives can be supported in addition to targeted fiscal measures by structural and competitiveness reforms, as well as macro- and microprudential instruments. As part of the EU's Macroeconomic Imbalance Procedure, aspects requiring targeted reforms have also emerged, such as the prevention of real estate bubbles and the early detection of declining competitiveness, rising private and public debt and investment gaps. 
In the case of a monetary union, national fiscal policy (general demand-stimulus or targeted measures) can stabilise Member States' economies, as there is no room for exchange rate adjustment and the adjustment of relative prices is slow. The effectiveness of fiscal policy with stabilisation purposes is strongly undermined by the fact that the estimation of the output gap in real time, i.e. when decisions are made, differed substantially from what appeared later in the light of the incoming data. We have shown that, as a consequence of the revision, a change in the sign of the output gap may have caused a problem for half of the EU Member States between 2000 and 2003, i.e. a fiscal policy meant to be counter-cyclical may have turned out to be pro-cyclical.

We have shown by simulation that a prolonged and large-scale fiscal expansion in general demand, despite the short-term benefits, can be costly, i.e. it may increase the debt ratio, assuming either weak Keynesian or neoclassical multipliers. In a specific situation (hysteresis), permanently higher multipliers may occur, however, even their extremes are insufficient to ensure that expansion does not substantially increase the debt ratio, i.e. self-financing is also not possible with higher GDP. In this sense, we can state that in the case of lasting and major problems, a general demand impulse is not a panacea. According to the OECD simulations, an alternative to this, namely structural reform, is a more appropriate instrument for a sustained increase in GDP, i.e. it may be less costly. Similar results were obtained in simulations processing the Hungarian experience of targeted measures.

\section{Literature}

Albertazzi, U. - Bottero, M. (2014): Foreign Bank Lending: Evidence from the Global Financial Crisis. Journal of International Economics, 92(Supplement 1): S22-S35. https://doi. org/10.1016/j.jinteco.2014.01.002

Alloza, M. - Cozmanca, B. - Ferdinandusse, M. - Jacquinot, P. (2019): Fiscal spillovers in a monetary union. ECB Economic Bulletin, Issue 1. https://www.ecb.europa.eu//pub/ economic-bulletin/articles/2019/html/ecb.ebart201901_02 5a37c33119.en.html

Auerbach, A.J. - Gorodnichenko, Y. (2012a): Fiscal multipliers in recession and expansion. In: Alesina, A. - Giavazzi, F. (eds.): Fiscal Policy after the Financial Crisis. Chicago, University of Chicago Press, pp. 63-98. https://doi.org/10.7208/chicago/9780226018584.003.0003

Auerbach, A. J. - Gorodnichenko, Y. (2012b): Measuring the Output Responses to Fiscal Policy. American Economic Journal: Economic Policy, 4(2): 1-27. https://doi.org/10.1257/pol.4.2.1

Baksa, D. - Benk, Sz. - Jakab, M.Z. (2014): Létezik „a” költségvetési multiplikátor? Fiskális és monetáris reakciók, hitelesség és költségvetési multiplikátorok Magyarországon 
(Does "The" Fiscal Multiplier Exist? Fiscal and Monetary Reactions, Credibility and Fiscal Multipliers in Hungary). Szigma, 45(1-2): 57-84.

Baksay, G. - Csomós, B. (2014): Az adó- és transzferrendszer 2010 és 2014 közötti változásainak elemzése viselkedési mikroszimulációs modell segitségével (Analysis of the Changes in the Hungarian Tax System and Social Transfers Between 2010 and 2014 Using a Behavioural Microsimulation Model). Köz-Gazdaság, 9(4): 31-60.

Barry, F. (1991): Irish Recovery 1987-90: Economic Miracle? Irish Banking Review, 1991(Winter): 23-40. https://core.ac.uk/download/pdf/16338738.pdf. Downloaded: 5 March 2020.

Batini, N. - Eyraud, L. - Forni, L. - Weber, A. (2014): Fiscal Multipliers: Size, Determinants, and Use in Macroeconomic Projections. IMF Technical Notes and Manuals 14/04, International Monetary Fund. https://doi.org/10.5089/9781498382458.005

Benczúr, P. - Kátay, G. - Kiss, Á. (2018): Assessing the economic and social impact of tax and benefit reforms: A general-equilibrium microsimulation approach applied to Hungary. Economic Modelling, 75(November): 441-457. https://doi.org/10.1016/j. econmod.2018.06.016

Bernheim, B.D. (1989): A Neoclassical Perspective on Budget Deficits. Journal of Economic Perspectives, 3(2): 55-72. https://doi.org/10.1257/jep.3.2.55

Bernhofer, D. - Fernández-Amador, O. - Gächter, M. - Sindermann, F. (2014): Finance, Potential Output and the Business Cycle: Empirical Evidence from Selected Advanced and CESEE Economies. Focus on European Economic Integration, 2014/2: 52-75.

Bi, H. - Shen, W. - Yang, S. (2014): Fiscal limits, external debt, and fiscal policy in developing countries. IMF Working Paper 14/49, International Monetary Fund. https://doi. org/10.5089/9781475521665.001

Blinder, A.S. (1975): Distribution effects and the aggregate consumption function. Journal of Political Economy, 83(3): 447-475. https://doi.org/10.1086/260337

Boone, L. - Buti, M. (2019): Right here, right now: The quest for a more balanced policy mix. Vox, CEPR Policy Portal, 18 October. https://voxeu.org/article/right-here-right-now-questmore-balanced-policy-mix. Downloaded: 11 March 2020.

Borio, C. - Disyatat, P. - Juselius, M. (2013): Rethinking potential output: Embedding information about the financial cycle. BIS Working Papers No. 404. https://www.bis.org/ publ/work404.pdf. Downloaded: 9 March 2020.

Bradley, J. - Whelan, K. (1997): The Irish expansionary fiscal contraction: A tale from one small European economy. Economic Modelling, 14(2): 175-201. https://doi.org/10.1016/ S0264-9993(96)01036-X 
Bussière, M. - Ferrara, L. - Juillard, M. - Siena, D. (2017): Can Fiscal Budget-Neutral Reforms Stimulate Growth? Model-Based Results. Banque de France, Working Paper No. 625. https://doi.org/10.2139/ssrn.2955120

Caudal, N. - Georges, N. - Grossmann-Wirth, V. - Guillaume, J. - Lellouch, T. - Sode, A. (2013): A budget for the euro area. Trésor-Economics, No. 120. https://www.tresor. economie.gouv.fr/Articles/7060c4e6-02c3-4e7b-a088-c6627826d8d7/files/febacdd88f92-4a02-9c0b-4c1c7dad5c38. Downloaded: 9 March 2020.

Cœuré, B. (2017): Scars or scratches? Hysteresis in the euro area. Speech at the International Center for Monetary and Banking Studies, Geneva, 19 May. https://www.ecb.europa.eu/ press/key/date/2017/html/ecb.sp170519.en.html. Downloaded: 3 March 2020.

CBO (2013): The Effects of Automatic Stabilizers on the Federal Budget as of 2013. Technical report, Congressional Budget Office. https://www.cbo.gov/publication/43977. Downloaded: 3 March 2020.

Chand, S.K. (1977): Summary Measures of Fiscal Influence. IMF Staff Papers, 24(2): 405-449. https://doi.org/10.2307/3866579

Chand, S.K. (1993): Fiscal Impulse Measures and Their Fiscal Impact. In: Blejer, M.I. - Cheasty, A. (eds): How to Measure Fiscal Deficit. International Monetary Fund, pp. 85-102.

Christiano, L.J. (1984): A reexamination of the theory of automatic stabilizers. Carnegie-Rochester Conference Series on Public Policy, 20(1): 147-206. https://doi. org/10.1016/0167-2231(84)90044-7

Cimadomo, J. (2008): Fiscal Policy in Real Time. ECB Working Paper No 919, European Central Bank. https://www.ecb.europa.eu/pub/pdf/scpwps/ecbwp919.pdf

Coenen, G. - Erceg, C.J. - Freedman, C. - Furceri, D. - Kumhof, M. - Lalonde, R. - Laxton, D. - Lindé, J. - Mourougane, A. - Muir, D. - Mursula, S. - de Resende, C. - Roberts, J. Roeger, W. - Snudden, S. - Trabandt, M. - in't Veld, J. (2012): Effects of Fiscal Stimulus in Structural Models. American Economic Journal: Macroeconomics, 4(1): 22-68. https:// doi.org/10.1257/mac.4.1.22

Cottarelli, C. - Keen, M. (2012): Fiscal Policy and Growth: Overcoming the Constraints. In: Canuto, O. - Leipziger, D.M. (eds): Ascent after Decline: Regrowing Global Economies after the Great Recession, January, pp. 87-133. https://doi.org/10.1596/9780821389423_CH03

DeLong, J.B. - Summers, L. (2012): Fiscal Policy in a Depressed Economy. Brookings Papers on Economic Activity, 43(1): 233-297. https://doi.org/10.1353/eca.2012.0000

Domar, E.D. (1944): The "Burden of the Debt" and the National Income. American Economic Review, 34(4): 798-827. 
Draghi, M. (2019): Stabilisation policies in a monetary union. Speech at the Academy of Athens, 1 October.

Dreyer, J.K. - Schmid, P.A. (2015): Fiscal federalism in monetary unions: hypothetical fiscal transfers within the Euro-zone. International Review of Applied Economics, 29(4): 506-532. http://doi.org/10.1080/02692171.2015.1016407

Duesenberry, J.S. - Eckstein, O. - Fromm, G. (1960): A Simulation of the United States in Recession. Econometrica, 28(October): 749-809. https://doi.org/10.2307/1907563

Eggertsson, G. - Ferrero, A. - Raffo, A. (2014): Can structural reforms help Europe? Journal of Monetary Economics? 61(January): 2-22. https://doi.org/10.1016/j.jmoneco.2013.11.006

Eichengreen, B. (1998): Comment on: Alesina, A. - Perotti, R. - Tavares, J. (1998): The political economy of fiscal adjustments. Brooking Papers on Economic Activity. https:// doi.org/10.2307/2534672

EC (1999): European Commission: The EU economy: 1999 review. No 69. https://ec.europa. eu/economy_finance/publications/pages/publication1732_en.pdf

EC (2000): European Commission: The EU economy: 2000 review. No 71. https://ec.europa. eu/economy_finance/publications/pages/publication1716_en.pdf

EC (2001): European Commission: The EU economy: 2001 review Investing in the future. No 73. https://ec.europa.eu/economy_finance/publications/pages/publication1708_en.pdf

EC (2002): European Commission: The EU economy: 2002 review. No 6. https://ec.europa. eu/economy_finance/publications/pages/publication489_en.pdf

EC (2016): European Commission: The Macroeconomic Imbalance Procedure, Rationale, Process, Application: A Compendium. Institutional Paper 039. https://ec.europa.eu/info/ publications/economy-finance/macroeconomic-imbalance-procedure-rationale-processapplication-compendium_en. Downloaded: 12 March 2020.

EFB (2019): European Fiscal Board: Assessment of the EU fiscal rules with a focus on the six and two-pack legislation. https://ec.europa.eu/info/publications/assessment-eu-fiscalrules-focus-six-and-two-pack-legislation_en. Downloaded: 12 March 2020.

Forni, L. - Momigliano, S. (2005): Cyclical Sensitivity of Fiscal Policies Based on Real-Time Data. Applied Economics Quarterly, 50(3): 299-326.

Giavazzi, F. - Jappelli, T. - Pagano, M. (2000): Searching for non-linear effects of fiscal policy: evidence from industrial and developing countries. European Economic Review, 44(7): 1259-1289. https://doi.org/10.1016/S0014-2921(00)00038-6 
Guajardo, J. - Leigh, D. - Pescatori, A. (2011): Expansionary Austerity: New International Evidence. IMF Working Paper No. 158, International Monetary Fund. https://www.imf. org/en/Publications/WP/Issues/2016/12/31/Expansionary-Austerity-New-InternationalEvidence-25021. Downloaded: 6 March 2020.

Guest, R. - Makin, A.J. (2011): In the Long Run, the Multiplier is Dead: Lessons from a Simulation. Agenda: A Journal of Policy Analysis and Reform, 18(1): 13-21. https://doi. org/10.22459/AG.18.01.2011.02

Hayashi, F. (1987): Tests for Liquidity Constraints: A Critical Survey and Some New Observations. In: Bewley, T. (ed.): Advances in Econometrics Fifth World Congress, 2, Cambridge University Press. https://doi.org/10.1017/CCOL0521345529.005

Heller, P. (2005): Back to basics - Fiscal Space: What It Is and How to Get It. Finance and Development, 42(2). https://www.imf.org/external/pubs/ft/fandd/2005/06/basics.htm. Downloaded: 3 March 2020.

Horváth, Á. - Jakab, M.Z. - P. Kiss, G. - Párkányi, B. (2006). Tények és talányok: Fiskális kiigazítások makrohatásai Magyarországon (Myths and Maths: Macroeconomic Effects of Fiscal Adjustments in Hungary). MNB Occasional Papers no. 52, Magyar Nemzeti Bank. https://www.mnb.hu/kiadvanyok/elemzesek-tanulmanyok-statisztikak/mnb-tanulmanyok/ mnb-tanulmanyok/op-52-horvath-agnes-jakab-m-zoltan-p-kiss-gabor-parkanyi-balazstenyek-es-talanyok-fiskalis-kiigazitasok-makrohatasai-magyarorszagon. Downloaded: 11 March 2020.

Huidrom, R. - Kose, M.A. - Lim, J.J. - Ohnsorge, F.L. (2016): Do fiscal multipliers depend on fiscal positions? Policy Research Working Paper Series 7724, The World Bank.

IMF (2015): Fiscal policy and long-term growth. International Monetary Fund. https://www. imf.org/en/Publications/Policy-Papers/Issues/2016/12/31/Fiscal-Policy-and-Long-TermGrowth-PP4964. Downloaded: 11 March 2020.

Jedrzejowicz, T. - P. Kiss, G. - Jirsakova, J. (2009): How to measure tax burden in an internationally comparable way? National Bank of Poland Working Papers No. 56, National Bank of Poland, Economic Institute. https://dx.doi.org/10.2139/ssrn.1752229

Jones, P.M. - Olson, E. - Wohar, M.E. (2015): Asymmetric tax multipliers. Journal of Macroeconomics, 43(March): 38-48. http://doi.org/10.1016/j.jmacro.2014.08.006

Juncker, J.-C. - Tusk, D. - Dijsselbloem, J. - Draghi, M. - Schulz, M. (2015): Completing Europe's Economic and Monetary Union. European Commission. https://ec.europa.eu/ commission/sites/beta-political/files/5-presidents-report_en.pdf. Downloaded: 10 March 2020. 
Lehmann, K. - Nagy, O. - Szalai, Z. - H. Váradi, B. (2020): Coordination(?) between the Branches of Economic Policy across the Euro Area. Financial and Economic Review, 19(1): 37-64. http://doi.org/10.33893/FER.19.1.3764

MNB (2015): Growth Report. Magyar Nemzeti Bank. https://www.mnb.hu/letoltes/engnovekedesijel-boritoval.pdf. Downloaded: 2 March 2020.

Mankiw, N.G. (2000): The Savers-Spenders Theory of Fiscal Policy. NBER working paper No 7571. http://doi.org/10.3386/w7571

Matolcsy, Gy. (2015): Economic Balance and Growth. Magyar Nemzeti Bank, Kairosz Kiadó, Budapest.

Morris, R. - Braz, C.R. - de Castro, F. - Jonk, S. - Kremer, J. - Linehan, S. - Marino, M.R. Schalck, C. - Tkacevs, O. (2009): Explaining government revenue windfalls and shortfalls an analysis for selected EU countries. ECB Working papers No 1114. https://www.ecb. europa.eu/pub/pdf/scpwps/ecbwp1114.pdf. Downloaded: 5 March 2020.

Mourre, G. - Poissonnier, A. - Lausegger, M. (2019): The Semi-Elasticities Underlying the Cyclically-Adjusted Budget Balance: An Update \& Further Analysis. European Commission Discussion paper 098/May.

Musgrave, R.A. (1959): Theory of Public Finances. McGraw-Hill, New York.

Nikolov, P. (2016): Cross-border risk sharing after asymmetric shocks: evidence from the euro area and the United States. Quarterly Report on the Euro Area, 15(2). https://ec.europa. eu/info/sites/info/files/ip030_en_1.pdf. Downloaded: 9 March 2020.

OECD (2016): Economic Policy Reforms 2016: Going for Growth Interim Report. OECD Publishing. https://doi.org/10.1787/growth-2016-en

OECD (2019a): OECD Economic Outlook. OECD Publishing. https://doi.org/10.1787/ b2e897b0-en

OECD (2019b): Economic Policy Reforms 2019: Going for Growth. OECD Publishing. https:// doi.org/10.1787/aec5b059-en

Palotai, D. (2017): Beértek a 2010-2013 közötti adóreform kedvezö hatásai (The favourable effects of the 2010-2013 tax reform have borne fruit). MNB Article, Magyar Nemzeti Bank. https://www.mnb.hu/letoltes/palotai-daniel-adoreform-gyumolcsei-mnb-honlapra.pdf. Downloaded: 12 March 2020.

Perotti, R. (1996): Fiscal Consolidation in Europe: Composition Matters. The American Economic Review, 86(2), Papers and Proceedings of the Hundredth and Eighth Annual Meeting of the American Economic Association San Francisco CA, January 5-7, 1996, pp. 105-110. https://www.jstor.org/stable/2118105?seq=1\#metadata_info_tab_contents. Downloaded: 11 March 2020. 
P. Kiss, G. (2011): Mozgó célpont? Fiskális mutatók jegybanki szemszögböl (Moving target indication: Fiscal indicators employed by the Magyar Nemzeti Bank). MNB Occasional Papers (MT92), Magyar Nemzeti Bank. https://www.mnb.hu/letoltes/mt92-vegleges.pdf. Downloaded: 6 March 2020.

P. Kiss, G. (2017): Mi nulla? Mi mennyi? Amit mindig tudni szerettél volna a kiegyensúlyozott költségvetésröl (What is zero? What is how much? What you always wanted to know about a balanced budget). Köz-Gazdaság, 12(4): 167-199.

Prammer, D. (2004): Expansionary Fiscal Consolidations? An Appraisal of the Literature on Non-Keynesian Effects of Fiscal Policy and case Study for Austria. OeNB, Monetary Policy \& the Economy Q3/2004. https://econpapers.repec.org/scripts/redir.pf?u=https\%3A\%2F\%2F www.oenb.at\%2Fdam\%2Fjcr\%3Ac476adcc-3bb8-42b4-bddc-6e00eb41194a\%2Fmop _20043_analyses3_tcm16-21309.pdf;h=repec:onb:oenbmp:y:2004:i:3:b:3. Downloaded: 5 March 2020.

Price, R. - Dang, T.-T. (2011): Adjusting Fiscal Balances for Asset Price Cycles. OECD Economics Department Working Papers No. 868. https://doi.org/10.1787/5kgc42t3zqkl-en

Rachel, L. - Summers, L. (2019): On Secular Stagnation in the Industrialized World. NBER Working Paper No 26198. https://doi.org/10.3386/w26198

Rogoff, K. (2016): Debt Supercycle, Not Secular Stagnation. Progress and Confusion: The State of Macroeconomic Policy. Cambridge: MIT Press, pp. 19-28. https://doi.org/10.7551/ mitpress/10678.003.0003

Romer, C.D. - Romer, D.H. (2010): The Macroeconomic Effects of Tax Changes: Estimates Based on a New Measure of Fiscal Shocks. American Economic Review, 100(3): 763-801. http://doi.org/10.1257/aer.100.3.763

Strulik, H. - Trimborn, T. (2013): The Dark Side of the Fiscal Stimulus. CEGE discussion paper no. 150, January. https://www.econstor.eu/bitstream/10419/70210/1/734961634.pdf. Downloaded: 4 March 2020.

Szoboszlai, M. - Bögöthy, Z. - Mosberger, P. - Berta, D. (2018): A 2010-2017 közötti adóés transzferváltozások elemzése mikroszimulációs modellel (Assessment of the Tax and Transfer Changes in Hungary Between 2010 and 2017 Using a Microsimulation Model). MNB Occasional Papers (MT135), Magyar Nemzeti Bank. https://www.mnb.hu/letoltes/ mnb-tanulma-ny-135-vegleges.pdf. Downloaded: 12 March 2020.

Tanzi, V. - Zee, H. (1997): Fiscal Policy and Long-Run Growth. IMF Staff Papers, 44(2): 179-209.

Triggs, A. (2018): The economic and political case for coordinating fiscal stimulus. Global Economy \& Development working paper 121, November. https://www.brookings.edu/wpcontent/uploads/2018/11/Triggs_Case-for-coordination-fiscal-stimulus.pdf. Downloaded: 12 March 2020. 